\title{
Effect of Moderate Hypocapnic Ventilation on Nuclear DNA Fragmentation and Energy Metabolism in the Cerebral Cortex of Newborn Piglets
}

\author{
KAREN I. FRITZ, QAZI M. ASHRAF, OM P. MISHRA, AND \\ MARIA DELIVORIA-PAPADOPOULOS \\ Department of Pediatrics, MCP Hahnemann University, St. Christopher's Hospital for Children, \\ Neonatology Research Laboratories, Medical College of Pennsylvania, Philadelphia, Pennsylvania 19131, \\ U.S.A.
}

\begin{abstract}
Previous studies have shown that severe hypocapnic ventilation [arterial carbon dioxide partial pressure $\left(\mathrm{PaCO}_{2}\right) 7-10 \mathrm{~mm}$ $\mathrm{Hg}]$ in newborn animals results in decreased cerebral blood flow and decreased tissue oxidative metabolism. The present study tests the hypothesis that moderate hypocapnic ventilation $\left(\mathrm{PaCO}_{2}\right.$ $20 \mathrm{~mm} \mathrm{Hg}$ ) will result in decreased cerebral oxidative metabolism and nuclear DNA fragmentation in the cerebral cortex of normoxemic newborn piglets. Studies were performed in 10 anesthetized newborn piglets. The animals were ventilated for $1 \mathrm{~h}$ to achieve a $\mathrm{PaCO}_{2}$ of $20 \mathrm{~mm} \mathrm{Hg}$ in the hypocapnic $(\mathrm{H})$ group $(n=5)$ and $\mathrm{PaCO}_{2}$ of $40 \mathrm{~mm} \mathrm{Hg}$ in the normocapnic, control (C) group $(n=5)$. Tissue oxidative metabolism, reflecting tissue oxygenation, was documented biochemically by measuring tissue ATP and phosphocreatine (PCr) levels. Cerebral cortical nuclei were purified, nuclear DNA was isolated, and DNA content was determined. DNA samples were separated, stained, and compared with a standard DNA ladder. Tissue PCr levels were significantly lower in the $\mathrm{H}$ group than the $\mathrm{C}$ group $(2.32 \pm$ 0.66 versus $3.73 \pm 0.32 \mu \mathrm{mol} / \mathrm{g}$ brain, $p<0.05$ ), but ATP levels were preserved. Unlike $\mathrm{C}$ samples, $\mathrm{H}$ samples displayed a smear pattern of small molecular weight fragments between 100 and
\end{abstract}

\section{ABSTRACT}

$12,000 \mathrm{bp}$. The density of DNA fragments was eight times higher in the $\mathrm{H}$ group than the $\mathrm{C}$ group, and DNA fragmentation varied inversely with levels of $\operatorname{PCr}(r=0.93)$. These data demonstrate that moderate hypocapnia of $1 \mathrm{~h}$ duration results in decreased oxidative metabolism that is associated with DNA fragmentation in the cerebral cortex of newborn piglets. We speculate that hypocapnia-induced hypoxia results in increased intranuclear $\mathrm{Ca}^{2+}$ flux, which causes protease and endonuclease activation, DNA fragmentation, and periventricular leukomalacia in newborn infants. (Pediatr Res 50: 586-589, 2001)

C, control

\section{Abbreviations}

CBF, cerebral blood flow

CP, cerebral palsy

H, hypocapnic

NMDA, N-methyl-D-aspartate

$\mathrm{PaCO}_{2}$, partial pressure of carbon dioxide in arterial blood

$\mathbf{P a O}_{2}$, partial pressure of oxygen in arterial blood

PCr, phosphocreatine

PVL, periventricular leukomalacia
Preterm and ill term infants are at risk for brain injury, subsequent neurodevelopmental delay, and $\mathrm{CP}$, partially because of alterations in CBF (1). In neonates, white matter ischemia often results in ultrasonographic evidence of PVL, which has been associated with the development of $\mathrm{CP}$ in human infants (2).

Brain ischemia has been associated with hypocapnia owing to the effect of $\mathrm{pH}$ and $\mathrm{CO}_{2}$ on cerebral vascular tone (3). In

Received August 4, 2000; accepted June 25, 2001.

Correspondence and reprint requests: Karen I. Fritz M.D., Department of Pediatrics, MCP Hahnemann University, St. Christopher's Hospital for Children, Neonatology Research Laboratories, Medical College of Pennsylvania, 3300 Henry Avenue, Heritage Building 7th Floor, Philadelphia, PA 19131, U.S.A.; e-mail: fritzki@hotmail.com

Supported by NIH HD-20337, NIH HD-38079 and NIH HL-07027. multiple studies both the degree and duration of hypocapnia have been associated with an increased incidence of PVL and $\mathrm{CP}$ in preterm infants (4-6). In one study of 251 infants $<34$ wk gestation, $50 \%$ of ventilated preterm infants with a $\mathrm{PaCO}_{2}$ $<17 \mathrm{~mm} \mathrm{Hg}$ at least once during the first $3 \mathrm{~d}$ of life, and $30 \%$ of those with $\mathrm{PaCO}_{2}$ of 7-20 mm Hg, developed CP or PVL or both (6). In a study of 26 ventilated preterm infants $<1500 \mathrm{~g}$, $23 \%$ of infants with $\mathrm{PaCO}_{2}$ values $<20 \mathrm{~mm} \mathrm{Hg}$ during the first $24 \mathrm{~h}$ of life developed cystic PVL compared with $6 \%$ of infants who had normal $\mathrm{PaCO}_{2}$ values during the same period (7). In another study of 103 preterm infants, the duration of hypocapnia (defined as a $\mathrm{PaCO}_{2} \leq 30 \mathrm{~mm} \mathrm{Hg}$ ) during the first $72 \mathrm{~h}$ of life was an independent predictor of PVL and was associated with 
the development of CP by 2 years of age (4). A recent study of 26 intubated 27- to 32-wk-old infants found that the timeaveraged $\mathrm{PaCO}_{2}$ was lower and time-averaged $\mathrm{pH}$ higher in infants with PVL than those with normal development on the third day of life (8). However, other studies have not found a relationship between hypocapnia and brain injury (9). In addition, in clinical studies many confounding variables contributing to brain injury may exist. To determine whether moderate hypocapnia does induce cerebral injury, newborn piglets were used to test the hypothesis that arterial blood $\mathrm{PaCO}_{2}$ values of 20 $\mathrm{mm} \mathrm{Hg}$ for $1 \mathrm{~h}$ result in alterations of cerebral energy metabolism and nuclear DNA fragmentation in the cerebral cortex.

\section{METHODS}

Studies were performed in two groups of anesthetized, ventilated 1- to 3-d-old piglets, five normocapnic (C) and five $\mathrm{H}$. The experimental protocol was approved by the Institutional Animal Care and Use Committee of MCP Hahnemann University. Anesthesia was induced with $4 \%$ halothane and maintained with $0.8 \%$ halothane. Lidocaine $1 \%$ was injected locally for performance of a tracheostomy and insertion of aortic and inferior vena caval catheters. Intravenous fentanyl $(10 \mu \mathrm{g} / \mathrm{kg}$ initially and every hour) and tubocurarine $(0.3 \mathrm{mg} / \mathrm{kg})$ were given, and the animals were placed on a volume ventilator using $75 \%$ nitrous oxide and $25 \%$ oxygen. Arterial blood $\mathrm{pH}$, $\mathrm{PaO}_{2}, \mathrm{PaCO}_{2}$, glucose, lactate, heart rate, and blood pressure were recorded every $15 \mathrm{~min}$ in all animals. Temperature was maintained with a warming blanket.

After $1 \mathrm{~h}$ of baseline ventilation, the piglets were either ventilated as normocapnic, control animals $(\mathrm{C})$ keeping $\mathrm{pH}>$ $7.30, \mathrm{PaO}_{2} 80-100 \mathrm{~mm} \mathrm{Hg}$, and $\mathrm{PaCO}_{2} 40 \mathrm{~mm} \mathrm{Hg}$, or as $\mathrm{H}$ with $\mathrm{PaCO}_{2} 20 \mathrm{~mm} \mathrm{Hg}$ and $\mathrm{PaO}_{2} 80-100 \mathrm{~mm} \mathrm{Hg}$ by adjusting the ventilator rate, usually from 25 to 50 breaths per minute. End-tidal $\mathrm{CO}_{2}$ values were monitored continuously in all animals. After $1 \mathrm{~h}$ of study ventilation the piglets were given an additional dose of fentanyl ( $10 \mu \mathrm{g} / \mathrm{kg}$ i.v. $)$, and the brains were removed, placed in liquid nitrogen within $4 \mathrm{~s}$, and stored at $-80^{\circ} \mathrm{C}$ for biochemical analysis.

Brain concentrations of ATP and PCr were determined by a coupled enzyme reaction (10). Cerebral cortical neuronal nuclei were isolated according to a modification of the method by Giuffrida et al. (11). Cortical tissue was homogenized in 15 volumes of a medium containing $0.32 \mathrm{M}$ sucrose, $10 \mathrm{mM}$

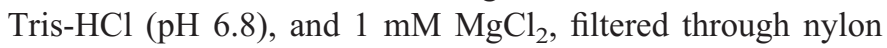
cloth (mesh 100), and centrifuged at $850 \times g$ for $10 \mathrm{~min}$. The pellet was resuspended and mixed with a medium containing 2.4 M sucrose, $10 \mathrm{mM}$ Tris- $\mathrm{HCl}$ (pH 6.8), and $1 \mathrm{mM} \mathrm{MgCl}_{2}$ to achieve a final concentration of $2.1 \mathrm{M}$ sucrose. The nuclei were purified by centrifugation at $53,000 \times g$ for $60 \mathrm{~min}$. Purity was assessed by phase-contrast microscopy. This method of neuronal nuclei isolation yields a $90-95 \%$ pure preparation (12).

DNA was isolated according to the method described by Higuchi and Linn (13). Cortical nuclei were centrifuged and resuspended in $50 \mathrm{mM}$ Tris- $\mathrm{HCl}(\mathrm{pH} 8.0), 100 \mathrm{mM}$ EDTA, and $0.5 \% \mathrm{SDS}$, then incubated with $10 \mathrm{mg} / \mathrm{mL}$ proteinase $\mathrm{K}$ at $55^{\circ} \mathrm{C}$. The digest was extracted with phenol (equilibrated with Tris $\mathrm{pH} 8.0$ ), the phases were separated by centrifugation, and the aqueous phase was isolated. The extraction was repeated with phenol-chloroform (1:1), the digest was shaken and centrifuged, and the aqueous phase was removed. DNA was precipitated with $3 \mathrm{M}$ sodium acetate $(\mathrm{pH}$ 6.0) and $100 \%$ ethanol at room temperature, then pelleted and washed with $70 \%$ ethanol. DNA was air-dried overnight and suspended with $10 \mathrm{mM}$ Tris (pH 8.0)-1 mM EDTA. DNA content was measured spectrophotometrically by absorbance at $260 \mathrm{~nm}$, and purity was confirmed by a ratio of $>1.7$ at $260 / 280 \mathrm{~nm}$.

Nuclear DNA $(0.2-0.5 \mu \mathrm{g})$ was dissolved in gel loading buffer $[0.25 \%$ bromophenol blue, $0.25 \%$ xylene cyanol $\mathrm{FF}$, $30 \%(\mathrm{vol} / \mathrm{vol})$ glycerol], and separated on a $1 \%$ agarose gel in Tris-boric acid-EDTA (TBE) buffer $(89 \mathrm{mM}$ Tris boric acid, 2 mM EDTA, $\mathrm{pH}$ 8.0). After electrophoresis the gel was stained with ethidium bromide $(0.5 \mu \mathrm{g} / \mathrm{mL}$ in TBE) and analyzed by Gel Doc-1000 system (Bio Rad, Hercules, CA). A ready load 1-kb DNA ladder was used as a molecular weight standard. The densities of the DNA fragments were assessed using Molecular Analyst (BioRad, Hercules, CA) and expressed as the OD $\times \mathrm{mm}^{2}$.

Statistical analysis between the two groups was performed by $t$ tests. A $p$ value $<0.05$ and an $r$ value $>0.05$ were considered statistically significant. Analysis of Figure 2 was performed using regression analysis and the best-curve fitting program of SigmaPlot/SigmaStat (Jandel Scientific, San Rafael, CA).

\section{RESULTS}

Baseline physiologic and blood measurements were similar in both the baseline $\mathrm{H}$ and $\mathrm{C}$ groups as shown in Table 1. After hypocapnia there was a significant increase in $\mathrm{pH}$ and decrease in $\mathrm{PaCO}_{2}$ in the $\mathrm{H}$ group compared with the $\mathrm{C}$ group $(p<0.001)$
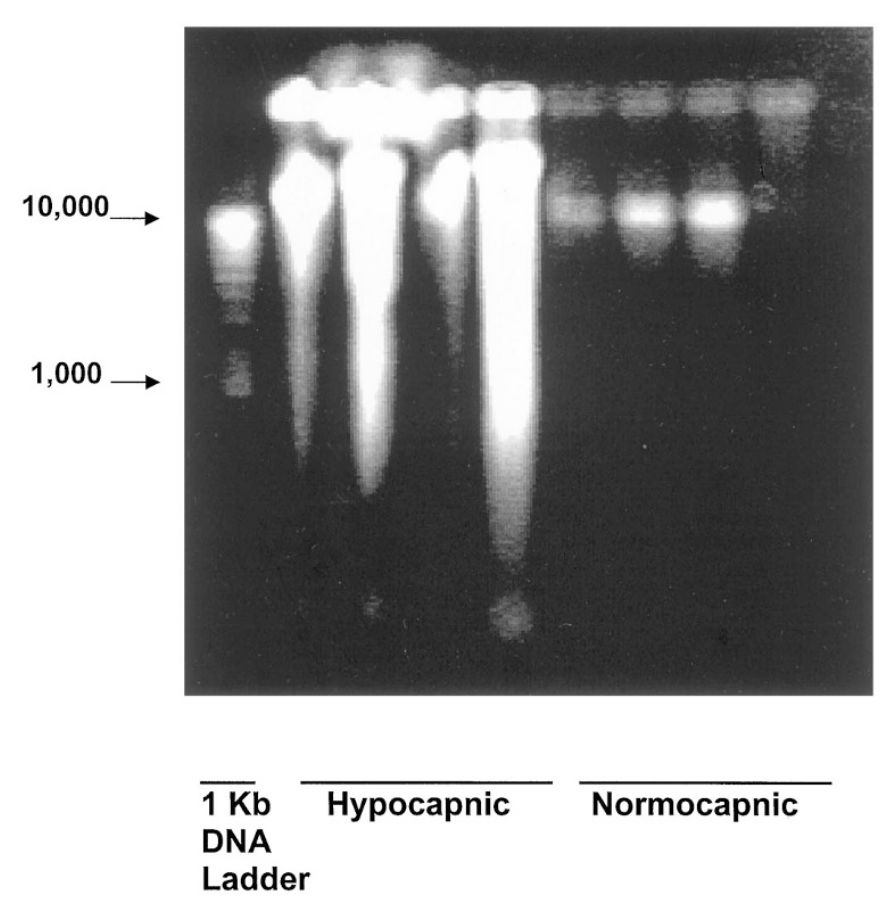

Figure 1. Gel electrophoresis of cortical DNA fragmentation in hypocapnic and normocapnic newborn piglets using a standard 1-kb DNA ladder. 
Table 1. Physiologic data of normocapnic and hypocapnic newborn piglets

\begin{tabular}{|c|c|c|c|c|c|c|c|}
\hline Groups & $\mathrm{pH}$ & $\begin{array}{c}\mathrm{PaCO}_{2} \\
(\mathrm{~mm} \mathrm{Hg})\end{array}$ & $\begin{array}{c}\mathrm{PaO}_{2} \\
(\mathrm{~mm} \mathrm{Hg})\end{array}$ & $\begin{array}{c}\text { Mean } \\
\text { BP } \\
(\mathrm{mm} \mathrm{Hg})\end{array}$ & $\begin{array}{l}\text { Heart rate } \\
\quad(\mathrm{bpm})\end{array}$ & $\begin{array}{l}\text { Lactate } \\
(\mathrm{nmol} / \mathrm{dL})\end{array}$ & $\begin{array}{c}\text { Glucose } \\
(\mathrm{mM})\end{array}$ \\
\hline Normocapnic & $7.45 \pm 0.03$ & $40 \pm 2$ & $92 \pm 7$ & $70 \pm 7$ & $190 \pm 40$ & $1.6 \pm 0.5$ & $6.5 \pm 0.7$ \\
\hline Hypocapnic experimental & $7.72 \pm 0.04 *$ & $20 \pm 1 *$ & $92 \pm 9$ & $69 \pm 10$ & $253 \pm 40 *$ & $2.3 \pm 0.6^{*}$ & $6.3 \pm 0.8$ \\
\hline
\end{tabular}

Mean \pm SD

Abbreviation used: BP, blood pressure.

$* p<0.05 v s$ normocapnic and hypocapnic baseline.

and $\mathrm{H}$ baseline period $(p<0.01)$. There was also a significant increase in serum lactate and heart rate in the $\mathrm{H}$ group compared with the $\mathrm{C}$ group $(p<0.01)$ and the $\mathrm{H}$ baseline period $(p$ $<0.01)$. However, there was no significant difference in mean blood pressure or glucose during hypocapnia.

Tissue $\mathrm{PCr}$ levels were $38 \%$ lower in the $\mathrm{H}$ group than the $\mathrm{C}$ group $(2.32 \pm 0.66$ versus $3.73 \pm 0.32 \mu \mathrm{mol} / \mathrm{g}$ brain, $p<$ $0.05)$, but ATP levels were preserved ( $4.6 \pm 0.5$ in the $\mathrm{H}$ group versus $4.6 \pm 0.3 \mu \mathrm{mol} / \mathrm{g}$ brain in the $\mathrm{C}$ group).

Unlike normocapnic piglets, hypocapnic piglets displayed a smear pattern of small molecular weight fragments between 100 and 12,000 bp (Fig. 1). The density of DNA fragments was eight times greater in the $\mathrm{H}$ group than the $\mathrm{C}$ group (1821 \pm 1229 versus $229 \pm 102 \mathrm{OD} \times \mathrm{mm}^{2}, p<0.05$ ). DNA fragmentation varied inversely with levels of $\operatorname{PCr}(r=0.93$; Fig. 2$)$.

\section{DISCUSSION}

These data demonstrate that moderate hypocapnia of $1 \mathrm{~h}$ duration results in a $38 \%$ decrease in brain tissue $\mathrm{PCr}$ levels and fragmentation of nuclear DNA in the cerebral cortex of newborn piglets. The decrease in tissue $\mathrm{PCr}$ levels indicates that there was a decrease in tissue oxygenation in the cerebral cortex during hypocapnia. In our previous studies we have shown that newborn piglets with lower $\mathrm{PaCO}_{2}$ levels $(9-11 \mathrm{~mm}$ $\mathrm{Hg}$ ) for $1 \mathrm{~h}$ had a reduction in tissue $\mathrm{PCr}$ values by $80 \%$ (14). Thus, the degree of reduction of tissue high-energy phosphates may correlate with the severity of hypocapnia. During ischemia-induced hypoxia, the storage form of high-energy phos-

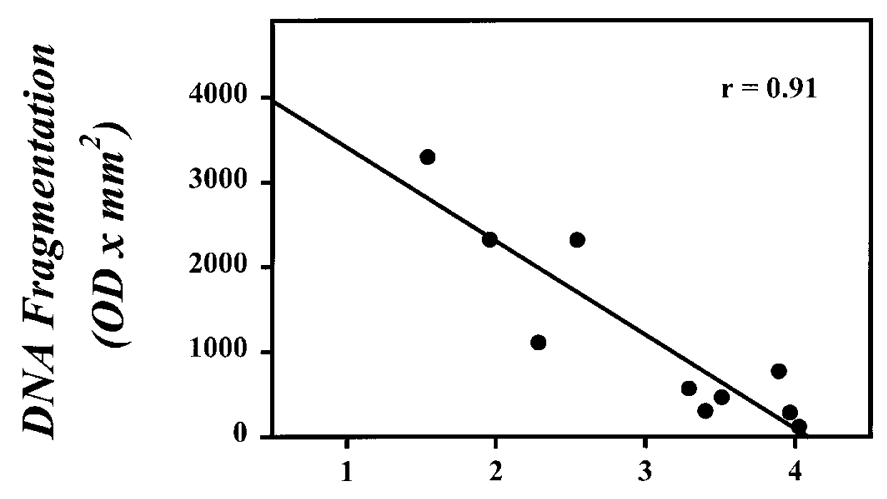

Phosphocreatine ( $\mu \mathrm{mol} / \mathrm{g}$ brain)

Figure 2. Linear correlation of DNA fragmentation and high-energy phosphates in the cerebral cortex of hypocapnic and normocapnic newborn piglets. phate, $\mathrm{PCr}$, is used before ATP to preserve cellular function (15). As a result, it is not until tissue PCr levels have been almost fully used that ATP levels decrease. In our present study the ischemia-induced hypoxia may not have been severe or long enough to decrease tissue ATP levels.

Hypocapnia may decrease cerebral tissue high-energy phosphates by reducing CBF (3), thereby decreasing oxygen and nutrient delivery to the brain. In our piglet model hyperventilation to a $\mathrm{PaCO}_{2}$ of $16 \mathrm{~mm} \mathrm{Hg}$ decreases $\mathrm{CBF}$ by $40 \%$ (16). Cerebral oxygenation may be further limited during hypocapnia as alkalosis shifts the oxyhemoglobin dissociation curve to the left and decreases tissue release of oxygen (3). Brain lactate levels are increased during hypocapnia and are proportional to $\mathrm{PaCO}_{2}$ levels (17), again suggesting that hypocapnia induces cerebral hypoxia. However, brain lactate production is also tissue $\mathrm{pH}$-dependent, and as $\mathrm{pH}$ increases, lactate production increases independent of oxygen availability, thus brain and serum lactate levels may reflect tissue oxygenation or tissue $\mathrm{pH}$ (18). In the present study the piglets had an increase in serum lactate levels and heart rate during hypocapnia. This may be related to hypocapnia-induced peripheral vasoconstriction. It is possible that these changes may be caused by decreased cardiac output from alterations in the ventilator strategy used. But inasmuch as arterial blood pressures were constant, the increase in ventilator rate used to induce hypocapnia was not thought to decrease cardiac output.

In our study there was a correlation between DNA fragment density and tissue PCr levels (Fig. 2) indicating that as tissue oxygenation decreased there was increased fragmentation of nuclear DNA. The linear correlation of $\mathrm{PCr}$ and DNA fragmentation does not appear to reflect a direct effect of tissue $\mathrm{PCr}$ levels on DNA fragmentation but rather reflects the trend that as tissue hypoxia worsens there is increased fragmentation of DNA. The increase in DNA fragmentation may be caused by increased intranuclear $\mathrm{Ca}^{2+}$ concentrations, which correlate with tissue $\mathrm{PCr}$ values during hypoxia (19).

Cerebral hypoxia results in increased intracellular $\mathrm{Ca}^{2+}$, which is proportional to the degree of hypoxia (20). Increased intracellular $\mathrm{Ca}^{2+}$ in turn activates proteases, phospholipases, and nitric oxide synthase $(21,22)$. Activation of these enzymes results in the generation of oxygen free radicals, peroxidation of nuclear membrane lipids, and activation of endonucleases leading to fragmentation of nuclear DNA (22-24).

Hypocapnia-induced DNA fragmentation may also be the result of increased intranuclear $\mathrm{Ca}^{2+}$ concentrations as a result of NMDA receptor activation $(25,26)$. In newborn piglets, severe hypocapnia $\left(\mathrm{PaCO}_{2} 9-11 \mathrm{~mm} \mathrm{Hg}\right)$ results in increased 
activation of the NMDA receptor by spermine and increased NMDA receptor sensitivity to activation by $\mathrm{Mg}^{2+}$ (14). Activation of NMDA receptors leads to increased intracellular $\mathrm{Ca}^{2+}$ flux (20). Intracellular $\mathrm{Ca}^{2+}$ is then transported into the nucleus by the high-affinity $\mathrm{Ca}^{2+}$-ATPase enzyme and by inositol 1,4,5-triphosphate and inositol 1,3,4,5-tetrakisphosphate receptors $(27,28)$. Increased intranuclear calcium activates endonucleases, which cut DNA at intranuclear cleavage sites, resulting in DNA fragmentation (29). NMDA receptor activation also results in the generation of oxygen free radicals, which peroxidize nuclear membrane lipids and may result in increased intranuclear $\mathrm{Ca}^{2+}$ and subsequent endonuclease activation, DNA fragmentation, and cell death $(21,22,24)$.

Neuronal cell death and DNA degradation have been described as occurring in two patterns - "early" or "necrotic" injury owing to increased $\mathrm{Na}^{+}$flux, resulting in cell swelling and lysis, and "late" or "programmed" cell death because of increased intracellular $\mathrm{Ca}^{2+}$ flux leading to the activation of proteases, phospholipases, and endonucleases and the synthesis of apoptotic proteins $(30,31)$. Early cell death has been associated with random DNA cleavage caused by the breakage of single strands of DNA resulting in a smear-type pattern on gel electrophoresis (31). Late cell death has been characterized by a laddertype pattern caused by DNA cleavage by endonucleases (31). Complete degradation of DNA by endonucleases results in a ladderlike pattern on gel electrophoresis with fragments 180-200 bp apart because of cleavage at internucleosomal sites $(29,30)$. During focal ischemic injury in the rat brain, both types of DNA fragmentation have been demonstrated (29).

In our study DNA fragmentation occurred after $1 \mathrm{~h}$ of hypocapnia in a smear-type pattern. The time frame $(1 \mathrm{~h})$ and smear pattern suggest that fragmentation is caused by the activation of proteases and necrotic cell injury rather than programmed cell death. However, the smear pattern of degradation observed in our study may be caused by either the action of proteases or the incomplete digestion of DNA by endonucleases. When intranuclear $\mathrm{Ca}^{2+}$ increases, nuclear proteases are activated, leading to the digestion of histone proteins. If protease activation precedes the activation of endonucleases, then degradation of histone proteins will allow random access of endonucleases to DNA and result in additional sites for the action of endonucleases and a nonspecific or smear pattern of DNA fragmentation. However, if endonucleases are activated first, before protease activation, they will cleave DNA at specific internucleosomal regions, producing a nucleosomesized ladder pattern (29). In this study, as in others (30), DNA fragmentation is not a "hallmark" of programmed cell death, but indicates that even during a brief episode of moderate hypocapnia there is damage of nuclear DNA and cortical injury in the newborn brain.

\section{CONCLUSION}

In summary, the data demonstrate that moderate hypocapnia of $1 \mathrm{~h}$ duration results in decreased oxidative metabolism and DNA degradation in the cerebral cortex of newborn piglets. We speculate that hypocapnia-induced hypoxia results in the modification of nuclear membranes, leading to increased intra- nuclear $\mathrm{Ca}^{2+}$ flux, which results in protease and endonuclease activation, DNA fragmentation, and PVL in the newborn brain.

\section{REFERENCES}

1. Volpe J 1998 Neurologic outcome of prematurity. Arch Neurol 55:297-300

2. Pidcock FS, Graziani LJ, Stanley C, Mitchell DG, Merton D 1990 Neurosonographic features of periventricular echodensities associated with cerebral palsy in preterm infants. J Peds 116:417-422

3. Brian Jr JE 1998 Carbon dioxide and the cerebral circulation. Anesthesiology 88:1365-1386

4. Ikonen RS, Janas MO, Koivikko MJ 1992 Hyperbilirubinemia, hypocarbia and periventricular leukomalacia in preterm infants: relationship to cerebral palsy. Acta Paediatr 81:802-807

5. Gannon CM, Wiswell TE, Spitzer AR 1998 Volutrauma, $\mathrm{PaCO}_{2}$ levels, and neurodevelopmental sequelae following assisted ventilation. Clinics Perinatol 25:159-175

6. Graziani LJ, Spitzer AR, Mitchell DG, Merton DA, Stanley C, Robinson N, McKee L 1992 Mechanical ventilation in preterm infants: neurosonographic and developmental studies. Pediatrics 90:515-522

7. Fujimoto S, Togari H, Yamaguchi N, Mizutani F, Suzuki S, Sobajima H 1994 Hypocarbia and cystic periventricular leukomalacia in premature infants. Arch Dis Child 71:F107-F110

8. Okumara A, Hayakawa F, Kato T, Itomi K, Maruyama K, Ishihara N, Kubota T, Suzuki M, Aato Y, Kuno K, Watanabe K 2001 Hypocarbia in preterm infants with periventricular leukomalacia: the relation between hypocarbia and mechanical ventilation. Pediatrics 107:469-475

9. Wiswell TE, Graziani LJ, Kornhauser MS, Cullen J, Merton DA, McKee L, Spitzer AR 1996 High-frequency jet ventilation in the early management of respiratory distress syndrome is associated with a greater risk for adverse outcomes. Pediatrics 98:1035-1043

10. Lamprecht W 1974 Creatine phosphate. In: Bergmeyer HU, ed. Methods of Enzymatic Analysis. Academic Press, New York, pp 1777-1781

11. Giuffrida AM, Cox D, Mathias AP 1975 RNA polymerase activity in various classes of nuclei from different regions of rat brain during post-natal development. J Neurochem 24:749-755

12. Austoker J, Cox D, Mathias AP 1972 Fractionation of nuclei from brain zonal centrifugation and a study of the ribonucleic acid polymerase activity in the various classes of nuclei. Biochem Res 129:1139-1155

13. Higuchi Y, Linn S 1995 Purification of all forms of Hela cell mitochondrial DNA and assessment of damage to it caused by hydrogen peroxide treatment of mitochondria or cells. J Biol Chem 270:7950-7956

14. Graham EM, Apostolou M, Mishra OP, Delivoria-Papadopoulos M 1996 Modification of the $N$-methyl-D-aspartate (NMDA) receptor in the brain of newborn piglets following hyperventilation induced ischemia. Neurosci Lett 218:29-32

15. Erecinska M, Silver IA 1989 ATP and brain function. J Cereb Blood Flow Metab 9:2-19

16. Hansen NB, Nowicki PT, Miller RR, Malone T, Bickers RG, Menke JA 1986 Alterations in cerebral blood flow and oxygen consumption during prolonged hypocarbia. Pediatr Res 20:147-150

17. Van Riejn PC, Luyten PR, van der Sprenkel JWB, Kraaier V, van Huffelen AC, Tulleken CAF, den Hollander JA $1989{ }^{1} \mathrm{H}$ and ${ }^{31} \mathrm{P}$ NMR measurement of cerebral lactate, high-energy phosphate levels, and $\mathrm{pH}$ in humans during voluntary hyperventilation: associated EEG, capnographic and Doppler findings. Magn Reson Med 10:182-193

18. Carlisson C, Nilsson L, Siesjo B 1974 Cerebral metabolic changes in arterial hypocapnia of short duration. Acta Anaesthesiol Scand 18:104-113

19. Akhter W, Zanelli SA, Ballesteros JR, Mishra OP, Delivoria-Papadopoulos M 2000 Effect of graded hypoxia on neuronal intranuclear calcium influx in newborn piglets. Pediatr Res 47:384A(abstr)

20. Zanelli SA, Numagami Y, McGowan JE, Mishra OP, Delivoria-Papadopoulos M 1999 NMDA receptor mediated calcium influx on cerebral cortical synaptosomes of the hypoxic guinea pig fetus. Neurochem Res 24:437-449

21. Halliwel B 1999 Antioxidant defense mechanisms: from the beginning to the end (of the beginning). Free Radic Res 31:261-272

22. Mishra OP, Delivoria-Papadopoulos M 1999 Cellular mechanisms of hypoxic injury in the developing brain. Brain Res Bull 48:233-238

23. Maulik D, Qayyum I, Powell SR, Karantza M, Mishra OP, Delivoria-Papadopoulos M 2001 Post-hypoxic magnesium decreases nuclear oxidative damage in the fetal guinea pig brain. Brain Res 890:130-136

24. Numagami Y, Zubrow AB, Mishra OP, Delivoria-Papadopoulos M 1997 Lipid free radical generation and brain cell membrane alteration following nitric oxide synthase inhibition during cerebral hypoxia in the newborn piglet. J Neurochem 69:1542-1547

25. Ikeda J, Terakawa S, Murota S, Morita I, Hirakawa K 1996 Nuclear disintegration as a leading step of glutamate excitotoxicity in brain neurons. J Neurosci Res 43:613-622

26. Nath R, Scott M, Nadimpalli R, Gupta R, Wang KK 2000 Activation of apoptosis-linked caspase(s) in NMDA-injured brains in neonatal rats. Neurochem Int 36:119-126

27. Gerasimenko OV, Gerasimenko JV, Tepikin AV, Petersen OH 1996 Calcium transport pathways in the nucleus. Eur J Physiol 432:1-6

28. Humbert J-P, Matter N, Artault J-C, Koppler P, Malviya AN 1996 Inositol 1,4,5triphosphate receptor is located to the inner nuclear membrane vindicating regulation of nuclear calcium signaling by inositol 1,4,5-triphosphate. J Biol Chem 271:478-485

29. Tominaga T, Kure S, Narisawa K, Yoshimoto T 1993 Endonuclease activation following focal ischemic injury in the rat brain. Brain Res 608:21-26

30. Collins RJ, Harmon BV, Gibe GC, Kerr JFR 1992 Internucleosomal DNA cleavage should not be the sole criterion for identifying apoptosis. Int J Radiat Biol 61:451-453

31. Compton MM 1991 Development of an apoptosis endonuclease assay. DNA Cell Biol 10:133-141 